\title{
Flame Atomic Absorption Spectrometric Determination of Palladium in Aqueous Samples after Preconcentration Using Nanoparticles of $\gamma$-Alumina Functionalized with Pyridine Groups
}

\author{
Ezatollah Najafi, Omid Sadeghi, Najmeh Tavassoli, Pari Mirahmadpour, and \\ Hamid Reza LOTFI ZadeH ZHAD ${ }^{\dagger}$ \\ $\mathrm{H}_{2} \mathrm{O}$ Group, Department of Chemistry, Islamic Azad University North Tehran Branch, \\ P. O. Box 1913674711, Tehran, Iran
}

\begin{abstract}
A new solid phase, nanoparticles of alumina functionalized with pyridine groups, was synthesized and used for extraction and preconcentartion of palladium(II) ions from some water samples. The effects of various parameters such as $\mathrm{pH}$, flow rates of sample and eluent, type and volume and concentration of eluent, sample volume, amount of adsorbent and cationic interferences have been studied and optimum conditions for best recovery have been obtained. The limit of detection of the method based on three times the standard deviation of the blank $\left(3 S_{\mathrm{b}}\right)$ was obtained: $0.6 \mathrm{ng} \mathrm{mL}^{-1}$. The preconcentration factor and the adsorption capacity were also calculated to be 60 and $37 \mathrm{mg} \mathrm{g}^{-1}$, respectively. The recovery of extraction of palladium ions on nano-alumina particles was determined to be $98.5 \%$. The utility of the modified nano-alumina was tested in some samples and showed an RSD value of $<0.8 \%$, reflecting its accuracy and reproducibility.
\end{abstract}

(Received January 9, 2010; Accepted February 11, 2010; Published April 10, 2010)

\section{Introduction}

Palladium is used in different areas of science and technology, including coating agents, brazing alloys, petroleum, electrical industries and catalytic chemical reactions. ${ }^{1,2}$ Thus, due to the increasing usage of it on one hand, and the toxicity of palladium(II) compounds to mammals, fish, and higher plants on the other hand, ${ }^{3}$ concerns about the effect of palladium on human health have been growing. Since palladium has no biological role, all palladium compounds should be regarded as highly toxic. ${ }^{4}$ Therefore determination and purification of palladium in waste water could be crucial.

Flame atomic absorption spectrometry (FAAS) is one of the most popular techniques for determination of metal ions because of its high specificity and low cost. However its sensitivity is usually insufficient for determination of trace metal ions in environmental samples. In order to overcome this problem and prevent interference effects, those who use this method usually include an efficient preconcentration step. ${ }^{5,6}$

So far, several methods for preconcentration and separation of trace amount of metals from various samples have been developed and used according to nature of the sample. ${ }^{7}$ Liquid-liquid microextraction, ${ }^{8}$ liquid-liquid extraction,,${ }^{9,10}$ membrane disk extraction, ${ }^{11}$ coprecipitation, ${ }^{12,13}$ cloud point extraction, ${ }^{14,15}$ leaching, ${ }^{16}$ cyanidation, ${ }^{17,18}$ adsorption process ${ }^{19}$ and solid phase extraction $(\mathrm{SPE})^{20-23}$ are the most popular methods for this aim. Among these techniques, SPE is one of the most important preconcentration methods because of its

$\dagger$ To whom correspondence should be addressed.

E-mail: hamidreza.lotfizadeh@gmail.com simplicity, flexibility of choice of the solid phase, high preconcentration factor, low consumption of the organic solvents, low cost and extraction time for sample preparation..$^{24-31}$ Nowadays, finding new materials as solid phase extractor is an important issue to determine transition metals at trace levels.

The possibility of synthesis of nanomaterials with a high surfaces area makes them a suitable solid phase. ${ }^{32-34}$ This structure can be functionalized ${ }^{35}$ and used in different applications such as catalyzers ${ }^{36,37}$ or metal extraction. ${ }^{38,39}$ Several solid phases have been developed for palladium extraction in recent decades. ${ }^{40-47}$ In this research, for the first time nanoparticles of alumina are functionalized with pyridine groups and used for extraction of trace amounts of palladium ions from some real samples of waste water. The optimum condition including flow rates of the sample and eluent solution, $\mathrm{pH}$ of the solution, type and least amount of eluent for elution were studied. Also amount of break-through-volume, maximum adsorption capacity and influence of various cationic interferences were investigated. This method can be applied as a reliable method for palladium enrichment and determination in complex environmental samples.

\section{Experimental}

\section{Apparatus}

A flame atomic absorption spectrometer (FAAS), Shimadzu AA-680 equipped with a single element palladium hollow cathode lamp (current $6.0 \mathrm{~mA}$ ) was used for determination of palladium(II). The operating conditions were as follows: wavelength $244.8 \mathrm{~nm}$, which is the resonance line for palladium; acetylene/air flow rate, $4.7 \mathrm{~L} \mathrm{~min}^{-1}$; and $0.5 \mathrm{~nm}$ for spectral 

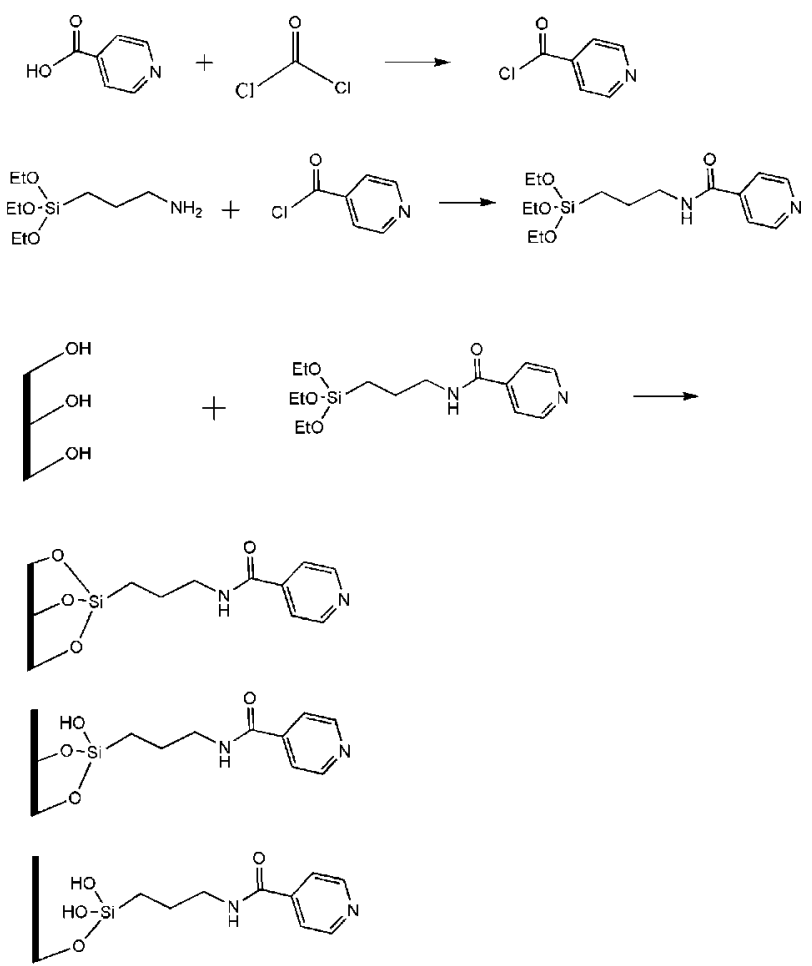

Fig. 1 A schematic model for synthesis of TPI and modifying nanoalumina with pyridine.

band width. The burner head was set at $5 \mathrm{~cm}$ during the experiment. A WTW Metrohm 827 ion analyzer (Switzerland), digital $\mathrm{pH}$ meter equipped with a combined glass-calomel electrode was used for all the $\mathrm{pH}$ measurements. All the $\mathrm{pH}$ measurements were made at $25 \pm 1{ }^{\circ} \mathrm{C}$. The vacuum pump used during the experiments was purchased from Leybold (Germany). A vacuum gauge controller was purchased from Analytichem International (Harbor City, CA).

\section{Chemicals and reagents}

All chemicals were reagent grade and were procured from Merck (Darmstadt, Germany) or Fluka (Buchs SG, Switzerland). Deionized water was used during the experiments. The buffer solutions applied for the required $\mathrm{pH}$ adjustments were: for $\mathrm{pH} 1-2, \mathrm{KCl} / \mathrm{HCl}$, for $\mathrm{pH} 4-6, \mathrm{CH}_{3} \mathrm{COOH} / \mathrm{CH}_{3} \mathrm{COONH}_{4}$; for $\mathrm{pH} 6-8, \mathrm{Na}_{2} \mathrm{HPO}_{4} / \mathrm{NaH}_{2} \mathrm{PO}_{4}$; and for $\mathrm{pH} 8-10, \mathrm{NH}_{3} / \mathrm{NH}_{4} \mathrm{Cl}$. $\mathrm{N}$-[3-(Triethoxysilyl)propyl]isonicotinamide (TPI) was synthesized according to the previously reported procedure (Fig. 1). ${ }^{48}$

\section{Preparation of pyridine-functionalized alumina}

Gamma alumina nanoparticles were prepared by the sol-gel method. Boehmite sol was prepared by the controlled hydrolysis of aluminum-tri-sec-butoxide. Details of the sol-gel synthesis are reported elsewhere. ${ }^{49}$ The sol was dried at $50^{\circ} \mathrm{C}$ to obtain gel pieces of boehmite. These boehmite gel pieces were heat-treated at $600^{\circ} \mathrm{C}$ to make $\gamma$-alumina. The sizes of the individual $\gamma$-alumina nanoparticles were $<10 \mathrm{~nm}$ and the pore size was measured as $3.96 \mathrm{~nm}$ by nitrogen adsorption. These nanoparticles were aggregated by heating to $1100^{\circ} \mathrm{C}$ for $6 \mathrm{~h}$ and then these were crushed into small aggregates. Afterwards, microparticles smaller than $2-20 \mu \mathrm{m}$ were separated by sieve.

The selected aggregates from such $\gamma$-alumina particles were attached to the tip of the AFM cantilever for force measurements.
The surface area of $\gamma$-alumina nanoparticle was measured as $197 \mathrm{~m}^{2} \mathrm{~g}^{-1}$ and the pore size was measured as $3.96 \mathrm{~nm}$ by nitrogen adsorption.

In a typical reaction, $1 \mathrm{~g} \gamma$-alumina was suspended in $50 \mathrm{~mL}$ toluene and the mixture was stirred for $1 \mathrm{~h}$; then $2.0 \mathrm{~g}$ of TPI was added and the mixture was refluxed for $2 \mathrm{~h}$. The white-brownish solid was removed from the solvent by filtration. In this step it was washed by toluene and chloroform, then dried at room temperature. Functionalization by pyridine was confirmed by elemental analysis. Elemental analyses of functionalization by IR spectroscopy are given below: IR ( $\mathrm{KBr}$, $\left.\mathrm{cm}^{-1}\right): 3445 \mathrm{~cm}^{-1}(\mathrm{NH}), 3045 \mathrm{~cm}^{-1}\left(\mathrm{CH}\right.$, aromatic), $2927 \mathrm{~cm}^{-1}$ (CH, aliphatic), $1653 \mathrm{~cm}^{-1}$ (CO), $1551 \mathrm{~cm}^{-1}$ (C=C), $1082 \mathrm{~cm}^{-1}$ ( $\mathrm{Si}-\mathrm{O}-\mathrm{Si})$. Elemental analysis of py- $\gamma$-alumina sample gave a pyridine concentration of $0.4 \mathrm{mmol} \mathrm{g}$.

\section{Column procedure for pretreatment and determination}

The modified alumina (200 mg) was packed in a glass column (120 mm in length and $20 \mathrm{~mm}$ in diameter) which was blocked at the ends with polypropylene filters to prevent absorbent leakage. The column was washed with $5 \mathrm{~mL}$ of hydrochloric acid $\left(1 \mathrm{~mol} \mathrm{~L}^{-1}\right), 5 \mathrm{~mL}$ of nitric acid $\left(1 \mathrm{~mol} \mathrm{~L}^{-1}\right), 5 \mathrm{~mL}$ of toluene, $5 \mathrm{~mL}$ of ethanol and $20 \mathrm{~mL}$ of distilled water to remove organic and inorganic contaminant. Fifty milliliters of palladium solution contaning $1 \mu \mathrm{g} \mathrm{mL}^{-1}$ concentration with $\mathrm{pH} 7$, adjusted by $\mathrm{Na}_{2} \mathrm{HPO}_{4} / \mathrm{NaH}_{2} \mathrm{PO}_{4}$ buffer solution, were passed through the column at a flow rate of $12 \mathrm{~mL} \mathrm{~min}^{-1}$. The palladium ions adsorbed on nano-alumina were eluted by $5 \mathrm{~mL}$ of $0.2 \mathrm{~mol} \mathrm{~L}^{-1}$ thiourea in $2 \mathrm{~mol} \mathrm{~L}^{-1} \mathrm{HCl}$ solution. The amount of palladium ions in the eluent was analyzed by FAAS for 5 replicate solutions and the results were averaged.

\section{Real sample pretreatment}

The tap sample water (Tehran, Iran) and the natural water samples obtained from the sea (Caspian Sea, Iran) and the Karaj river (Karaj, Iran) were analyzed with the proposed procedure. To pretreat the samples, filtered them through nylon filters (Millipore) and adjusted the $\mathrm{pH}$ to 7 by $\mathrm{Na}_{2} \mathrm{HPO}_{4} / \mathrm{NaH}_{2} \mathrm{PO}_{4}$ buffer solution.

\section{Results and Discussion}

\section{Influence of $\mathrm{pH}$}

In order to study the effect of $\mathrm{pH}$ on the recovery of palladium(II) with the functionalized nano-alumina, we adjusted $50 \mathrm{~mL}$ of sample solution containing $5 \mathrm{mg} \mathrm{L}^{-1}$ palladium in the $\mathrm{pH}$ range $2-10$ and passed the solution through the column. The retention ions on nano-alumina was eluted with $5 \mathrm{~mL}$ of $0.2 \mathrm{~mol} \mathrm{~L}^{-1}$ thiourea in $2 \mathrm{~mol} \mathrm{~L}^{-1} \mathrm{HCl}$ and analyzed by FAAS.

The obtained results are shown in Fig. 2. As can be seen, high deposition recovery of palladium was achieved at neutral $\mathrm{pH} 7$. It might be because of free lone pairs of electrons of pyridine at this $\mathrm{pH}$.

\section{Effect of type, concentration and volume of eluent}

For choice of the most effective eluent for desorbing the adsorbed metal ions on sorbent, different concentrations and volumes of $\mathrm{HCl}, \mathrm{HNO}_{3}$ and thiourea were used and the results were compared. The results given in Table 1 indicate that the highest recovery values are obtained at $5 \mathrm{~mL}$ of $0.2 \mathrm{~mol} \mathrm{~L}^{-1}$ thiourea in $2 \mathrm{~mol} \mathrm{~L}^{-1} \mathrm{HCl}$. Thus this concentration was selected as optimum. 


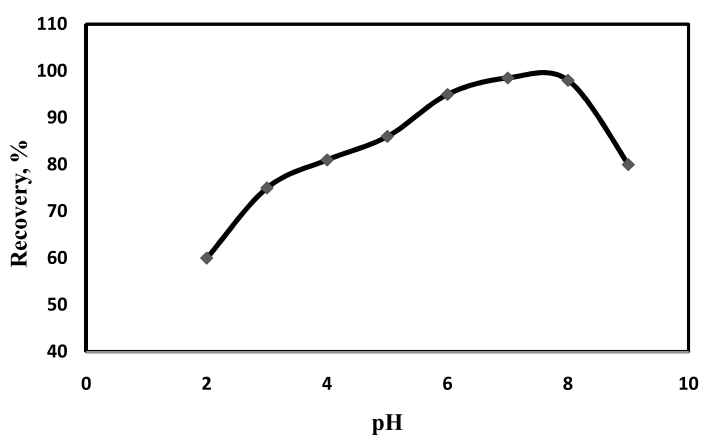

Fig. 2 Effect of $\mathrm{pH}$ of sample solution on the percent recovery of $\mathrm{Pd}(\mathrm{II})$ by py-alumina. Conditions: sample concentration, $5 \mathrm{mg} \mathrm{L}^{-1}$; sample volume, $50 \mathrm{~mL}$; eluent, $5 \mathrm{~mL}$ of $0.2 \mathrm{~mol} \mathrm{~L}^{-1}$ thiourea in

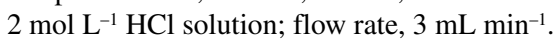

Table 1 Effects of type and concentration of eluent on desorption of $\mathrm{Pd}(\mathrm{II})$ by py-alumina

\begin{tabular}{|c|c|}
\hline Eluent & Recovery, \% \\
\hline $\mathrm{HNO}_{3} 1 \mathrm{~mol} \mathrm{~L}^{-1}$ & 28 \\
\hline $\mathrm{HNO}_{3} 2 \mathrm{~mol} \mathrm{~L}^{-1}$ & 32 \\
\hline $\mathrm{HNO}_{3} 3 \mathrm{~mol} \mathrm{~L}^{-1}$ & 38 \\
\hline $\mathrm{HCl} 1 \mathrm{~mol} \mathrm{~L}^{-1}$ & 35 \\
\hline $\mathrm{HCl} 2 \mathrm{~mol} \mathrm{~L}^{-1}$ & 41 \\
\hline $\mathrm{HCl} 3 \mathrm{~mol} \mathrm{~L}^{-1}$ & 54 \\
\hline $\mathrm{HNO}_{3} 1 \mathrm{~mol} \mathrm{~L}^{-1}+\mathrm{HCl} 2 \mathrm{~mol} \mathrm{~L}^{-1}$ & 50 \\
\hline $\mathrm{HNO}_{3} 2 \mathrm{~mol} \mathrm{~L}^{-1}+\mathrm{HCl} 1 \mathrm{~mol} \mathrm{~L}^{-1}$ & 39 \\
\hline Thiourea $0.1 \mathrm{~mol} \mathrm{~L}^{-1}+\mathrm{HCl} 2 \mathrm{~mol} \mathrm{~L}^{-1}$ & 77 \\
\hline Thiourea $0.2 \mathrm{~mol} \mathrm{~L}^{-1}+\mathrm{HCl} 2 \mathrm{~mol} \mathrm{~L}^{-1}$ & 93 \\
\hline Thiourea $0.2 \mathrm{~mol} \mathrm{~L}^{-1}+\mathrm{HCl} 1 \mathrm{~mol} \mathrm{~L}^{-1}$ & 98 \\
\hline Thiourea $0.1 \mathrm{~mol} \mathrm{~L}^{-1}+\mathrm{HNO}_{3} 2 \mathrm{~mol} \mathrm{~L}^{-1}$ & 71 \\
\hline Thiourea $0.2 \mathrm{~mol} \mathrm{~L}^{-1}+\mathrm{HNO}_{3} 2 \mathrm{~mol} \mathrm{~L}^{-1}$ & 76 \\
\hline
\end{tabular}

\section{Sample and eluent flow rates}

The retention of an element on an adsorbent also depends on the flow rate of the sample solution. Thus, the influence of flow rates of the sample and elution solutions on the retention and recovery of ions was studied under the optimum condition. Different flow rates in the range of $1-15 \mathrm{~mL} \mathrm{~min}^{-1}$ obtained by using a peristaltic pump were passed through the column and then the column was washed with $5 \mathrm{~mL}$ of eluent at different flow rates. As shown in Fig. 3, the flow rates of $1-12 \mathrm{~mL} \mathrm{~min}{ }^{-1}$ was chosen as optimum value for adsorption. Hence, beyond the value of $3 \mathrm{~mL} \mathrm{~min}^{-1}$ the recovery of extraction decreased significantly and the time of analysis would be increased in lower flow rates. Thus, $3 \mathrm{~mL} \mathrm{~min}{ }^{-1}$ was chosen as the optimum flow rate for desorption.

\section{Column reuse}

In order to investigate the long-term stability of solid phase for successive sorption and elution cycles, we passed a solution containing $100 \mathrm{~mL}$ of $1 \mu \mathrm{g} \mathrm{mL}^{-1}$ palladium(II) through the column with the proposed procedure and eluted with the optimum eluent. By monitoring changes in recovery of extracted palladium ions, we observed that after 8 sorption-desorption cycles the recovery decreased. The column could be recovered by washing with $10 \mathrm{~mL}$ of aqua regia $2 \mathrm{M}, 5 \mathrm{~mL}$ of absolute ethanol, and $5 \mathrm{~mL}$ of toluene, by passing $20 \mathrm{~mL}$ of distilled water and finally placing it in oven at $40^{\circ} \mathrm{C}$ for $6 \mathrm{~h}$.

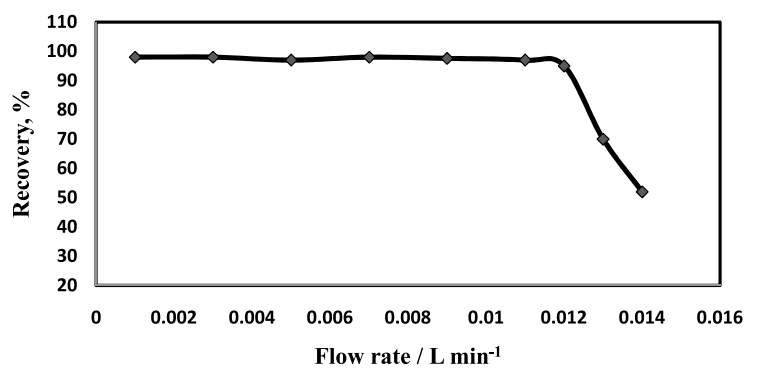

Fig. 3 Effect of flow rates of sample solutions on the percent recovery of $\mathrm{Pd}(\mathrm{II})$ by py-alumina. Conditions: sample concentration, $1 \mathrm{mg} \mathrm{L}^{-1}$; sample volume, $100 \mathrm{~mL}$; $\mathrm{pH}$, 7; eluent, $5 \mathrm{ml}$ of $0.2 \mathrm{~mol} \mathrm{~L}^{-1}$

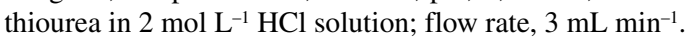

Table 2 The tolerance limit of diverse ions on the determination of palladium

\begin{tabular}{lcc}
\hline Interfering ion & $\begin{array}{c}\text { Tolerable } \\
\text { concentration }\end{array}$ & Recovery, \% \\
\hline $\mathrm{Na}^{+}$ & 2000 & 98.5 \\
$\mathrm{~K}^{+}$ & 2000 & 96.0 \\
$\mathrm{Cs}^{+}$ & 1000 & 93.7 \\
$\mathrm{Ca}^{2+}$ & 500 & 96.4 \\
$\mathrm{Mg}^{2+}$ & 500 & 94.9 \\
$\mathrm{Fe}^{2+}$ & 250 & 95.0 \\
$\mathrm{Cd}^{2+}$ & 500 & 95.3 \\
$\mathrm{Mn}^{2+}$ & 500 & 94.1 \\
$\mathrm{~Pb}^{2+}$ & 350 & 92.5 \\
$\mathrm{Cr}^{3+}$ & 350 & 96.4 \\
\hline
\end{tabular}

Conditions: $\mathrm{Pd}$ concentration, $1 \mu \mathrm{g} \mathrm{mL} \mathrm{m}^{-1}$; $\mathrm{pH}$, 7; sample volume, $100 \mathrm{~mL}$; eluent, $5 \mathrm{~mL}$ of $0.2 \mathrm{~mol} \mathrm{~L}^{-1}$ thiourea in $2 \mathrm{~mol} \mathrm{~L}^{-1} \mathrm{HCl}$ solution. Sample flow rate, $12 \mathrm{~mL} \mathrm{~min}^{-1}$; eluent flow rate, $3 \mathrm{~mL} \mathrm{~min}^{-1}$.

\section{Influence of interference ions}

To investigate the applications of the proposed solid phase on real samples, we exammed the effects of various cations that can be found in natural water samples on the extraction of palladium(II). For this purpose, model solutions containing different concentrations of chloride salts of $\mathrm{Na}^{+}, \mathrm{K}^{+}, \mathrm{Cs}^{+}, \mathrm{Mg}^{2+}$, $\mathrm{Ca}^{2+}, \mathrm{Cd}^{2+}, \mathrm{Fe}^{2+}, \mathrm{Pb}^{2+}, \mathrm{Mn}^{2+}$ and $\mathrm{Cr}^{+3}$ were added individually to a $100-\mathrm{mL}$ of single solution containing $0.001 \mathrm{~g}$ of palladium(II). As given in Table 2, none of the common metals interfered with the recovery of palladium.

\section{Analytical performance}

To determine the adsorption capacity of the nano-alumina, we passed $500 \mathrm{~mL}$ of aqueous single solution containing $100 \mathrm{mg}$ palladium through the column, followed by determination of the effluent and the retained metal ions using FAAS. According to the results, the adsorption capacity was found to be $37 \mathrm{mg} \mathrm{g}^{-1}$ $\left(0.35 \mathrm{mmol} \mathrm{g}^{-1}\right)$. The breakthrough volume of sample solution was examined by solving $1 \mathrm{mg}$ of palladium in $100,200,500$, $1000,1500,2000 \mathrm{~mL}$ distilled water and passing the solution through the column under optimal condition. It was observed that palladium ions could be obtained with recovery values more than $98 \%$ from $2000 \mathrm{~mL}$ and smaller volumes.

Five hundred milliliters of ten blank solutions were passed through the column under the optimal conditions and according to the measurement the detection limit was calculated to be $0.6 \mathrm{ng} \mathrm{mL}^{-1}$ from $C_{\mathrm{LOD}}=K_{\mathrm{b}} S_{\mathrm{b}} / m$ for a numerical factor of $k_{\mathrm{b}}=3$. 
Table 3 Data of real sample analysis for Pd on py-alumina

\begin{tabular}{lcrrc}
\hline & $\begin{array}{c}\text { Real sample/ } \\
\text { ng mL }\end{array}$ & $\begin{array}{r}\text { Added/ } \\
\mathrm{ng} \mathrm{mL}^{-1}\end{array}$ & $\begin{array}{c}\text { Found/ } \\
\mathrm{ng} \mathrm{mL}^{-1}\end{array}$ & $\begin{array}{c}\text { Recovery, } \\
\%\end{array}$ \\
\hline Distilled water & $\mathrm{ND}$ & 3.00 & $2.88 \pm 0.10$ & 96 \\
Tap water & $\mathrm{ND}$ & 3.00 & $2.83 \pm 0.10$ & 94 \\
Waste water & $4.92 \pm 0.10$ & 10.00 & $14.51 \pm 0.10$ & 97 \\
River water & $\mathrm{ND}$ & 3.00 & $2.86 \pm 0.10$ & 95 \\
Seawater & $\mathrm{ND}$ & 3.00 & $2.90 \pm 0.10$ & 96 \\
\hline
\end{tabular}

ND, Not detected.

Table 4 A comparison between this work and similar works

\begin{tabular}{lccc}
\hline \multicolumn{1}{c}{ Sorbent } & LOD/ng ml & $\begin{array}{c}\text { Maximum } \\
\text { capacity/mg g }\end{array}$ & Ref. \\
\hline Dithizone on nano-alumina & 4 & Not reported & 50 \\
$\alpha$-Amino pyridine resine & 9 & Not reported & 51 \\
Ion-imprinted polymer & Not reported & 18.76 & 52 \\
Ion-imprinted polymer & 5 & 0.026 & 53 \\
This work & 0.6 & 37 & - \\
\hline
\end{tabular}

The preconcentration factor was calculated to be 60 as the ratio of the highest sample volume for the analyte $(300 \mathrm{~mL})$ and the lowest eluent volume $(5.0 \mathrm{~mL})$ with no decreasing in recovery.

The recovery of extraction of palladium ion on nano-alumina was determined to be $98.5 \%$ with a relative standard deviation (RSD) of $98.5 \pm 0.8 \%$ for ten replicated analysis. The proposed method was performed on real samples in order to study its accuracy. The results showed that quantitative recovery of palladium with recovery of $98 \%$ was possible in natural water (Table 3).

\section{Conclusion}

The proposed solid phase extraction procedure based on nanoalumina functionalized with pyridine group shows a good selectivity for preconcentration and determination of palladium ions in trace levels. Due to relatively high enrichment factor, high capacity factor and low detection limit, palladium at trace level can be determined by this rapid and selective proposed method. Considering the neutral $\mathrm{pH}$ as the optimum condition for the extraction makes the method not only useable for measuring trace amounts of palladium in water but also a possible method for refining palladium from waste waters and reusing material again. A comparison between this method and similar methods is listed in Table 4, which shows a lower detection limit and higher capacity factor for this work.

\section{References}

1. D. A. Kezler and J. A. Ibers, Inorg. Chem., 1983, 22, 3366.

2. K. Machida, M. Enyo, G. Adachi, and J. Shiokawa, Bull. Chem. Soc. Jpn., 1987, 60, 411.

3. S. D. Lee, "Biochemical Aspects of Environmental Pollutants", 1980, Ann Arbor Science Publishers, Ann Arbor, MI.

4. J. Fang, Y. Jiang, X. P. Yan, and Z. M. Ni, Environ. Sci. Technol., 2005, 39, 288.
5. B. Y. Spivakov, G. I. Malofeeva, and O. M. Petrukhin, Anal. Sci., 2006, 22, 503.

6. V. N. Bulut, A. Gundogdu, C. Duran, H. B. Senturk, and M. Soylak, J. Hazard. Mater., 2007, 146, 155.

7. M. Balcerzak, Anal. Sci., 2002, 18, 737.

8. T. Ahmadzadeh Kokya and K. Farhadi, J. Hazard. Mater., 2009, 169, 726.

9. M. Domínguez, E. Anticó, L. Beyer, A. Aguirre, S. García-Granda, and V. Salvadó, Polyhedron, 2002, 21, 1429.

10. A. N. Anthemidis, D. G. Themelis, and J. A. Stratis, Talanta, 2001, 54, 37.

11. K. Farhadi and G. Teimouri, Talanta, 2005, 65, 925.

12. M. Soylak and M. Tuzen, J. Hazard. Mater., 2008, 152, 656.

13. H. Niskavaara and E. Kontas, Anal. Chim. Acta, 1990, 231, 273.

14. L. Tavakoli, Y. Yamini, H. Ebrahimzadeh, A. Nezhadali, Sh. Shariati, and F. Nourmohammadian, J. Hazard. Mater., 2008, 152, 737.

15. N. Shokoufi, F. Shemirani, and M. Shokoufi, Spectrochim. Acta, Part A, 2009, 74, 761.

16. C. Nowottny, W. Halwachs, and K. Schügerl, Sep. Purif. Technol., 1997, 12, 135.

17. C. M. McInnes, G. J. Sparrow, and J. T. Woodcock, Hydrometallurgy, 1994, 35, 141.

18. W. J. Bruckard, K. J. McDonald, C. M. McInnes, G. J. Sparrow, and J. T. Woodlock, Hydrometallurgy, 1992, 30, 211.

19. Z. Hubicki and A. Wołowicz, Hydrometallurgy, 2009, 96, 159.

20. J. Fang, L. Liu, and X. Yan, Spectrochim. Acta, Part B, 2006, 61, 864.

21. B. Godlewska-Żyłkiewicz and M. Kozłowska, Anal. Chim. Acta, 2005, 539, 61.

22. I. A. Kovalev, L. V. Bogacheva, G. I. Tsysin, A. A. Formanovsky, and Yu. A. Zolotov, Talanta, 2000, 52, 39.

23. G. Philippeit and J. Angerer, J. Chromatogr., B, 2001, 760, 237.

24. W. Ngeontae, W. Aeungmaitrepirom, and T. Tuntulani, Talanta, 2007, 71, 1075.

25. I. Komjarova and R. Blust, Anal. Chim. Acta, 2006, 576, 221.

26. F. Xie, X. Lin, X. Wu, and Z. Xie, Talanta, 2008, 74, 836.

27. C. Duran, A. Gundogdu, V. Bulut, M. Soylak, and L. Elci, J. Hazard. Mater., 2007, 146, 347.

28. I. Narin and M. Soylak, Talanta, 2003, 60, 215.

29. M. Ghaedi, Chem. Anal., 2006, 51, 693.

30. M. Ghaedi, M. R. Fathi, A. Shokrollahi, and F. Shajarat, Anal. Lett., 2006, 39, 1171.

31. M. Ghaedi and A. Shokrollahi, Fresenius Environ. Bull., 2006, 15, 1373.

32. J. Li, X. Zhao, Y. Shi, Y. Cai, Sh. Mou, and G. Jiang, J. Chromatogr., A, 2008, 1180, 24.

33. S. Shirvani-Arani, S. J. Ahmadi, A. Bahrami-Samani, and M. Ghannadi-Maragheh, Anal. Chim. Acta, 2008, 623, 82.

34. M. Karwa, D. Hahn, and S. Mitra, Anal. Chim. Acta, 2005, 546, 22.

35. A. Patra, E. Sominska, S. Ramesh, Yu. Koltypin, Z. Zhong, H. Minti, R. Reisfeld, and A. Gedanken, J. Phys. Chem., 1999, 103, 3361.

36. Y. Zhang, M. Koike, R. Yang, S. Hinchiranan, T. Vitidsant, and N. Tsubaki, Appl. Catal., A, 2005, 292, 252.

37. T. Oikawa, Y. Masui, T. Tanaka, Y. Chujo, and M. Onaka, $J$. Organomet. Chem., 2007, 692, 554. 
38. M. E. Mahmoud, A. A. Yakout, S. B. Ahmed, and M. M. Osman, J. Hazard. Mater., 2008, 158, 541.

39. M. Ghaedi, Kh. Niknam, A. Shokrollahi, E. Niknam, H. Rajabi, and M. Soylak, J. Hazard. Mater., 2008, 155, 121.

40. T. Saitoh, S. Suzuki, and M. Hiraide, J. Chromatogr., A, 2005, 179, 1097.

41. Q. Hu, X. Yang, Z. Huang, J. Chen, and G. Yang, J. Chromatogr., A, 2005, 77, 1094.

42. B. Godlewska-Zylkiewicz and M. Kozlowska, Anal. Chim. Acta, 2005, 61, 539.

43. Z. Fan, Chem. J. Internet., 2004, 6, 23.

44. K. Farhadi and G. Teimouri, Anal. Lett., 2004, 37, 1457.

45. I. A. Kovalev, L. V. Bogacheva, G. I. Tsysin, A. A. Formanovsky, and Y. A. Zolotov, Talanta, 2000, 52, 39.

46. F. Sinner, M. R. Buchmeiser, R. Tessadri, M. Mupa, K. Wurst, and G. K. Bonn, J. Am. Chem. Soc., 1998, 120,
2790.

47. L. Elci, M. Soylak, A. Uzun, E. Buyukpatir, and M. Dogan, Fresenius' J. Anal. Chem., 2000, 368, 358.

48. J. Hoogboom, P. M. L. Garcia, M. B. J. Otten, J. A. A. W. Elemans, J. Sly, S. V. Lazarenko, T. Rasing, A. E. Rowan, and R. J. M. Nolte, J. Am. Chem. Soc., 2005, 127, 11047.

49. Y. K. Park, E. H. Tadd, M. Zubris, and R. Tannenbaum, Mater. Res. Bull., 2005, 40, 1506.

50. W. Xiong, F. Zhou, and Y. Shu, Fenxi Ceshi Xuebao, 2006, 25, 52.

51. P. Di and D. E. Davey, Talanta, 1995, 42, 685.

52. S. Daniel, P. P. Rao, and T. P. Rao, Anal. Chim. Acta, 2005, 536, 197.

53. S. Daniel, P. E. J. Babu, and T. P. Rao, Talanta, 2005, 65, 441. 